\title{
Tax crimes in Italy using accounting documents
}

\author{
RafaŁ CIEŚLA \\ ORCID: 0000-0002-8479-288X \\ Department of Forensic Sciences, Faculty of Law, Administration and Economics \\ University of Wrocław, Poland \\ Pietro Pavone \\ ORCID: 0000-0001-5880-8609 \\ University of Sannio, Italy \\ JolANTA GręBOWIEC-BAFFONI \\ ORCID: 0000-0002-5739-8190 \\ Center for Economics and Law Studies, Legnano, Italy
}

\begin{abstract}
Contemporary document research involves the need to use the latest technologies and analytical techniques that provide the most complete possible knowledge of contemporary issues and methods of document research. Documents are used to record legal actions and events of legal significance. By their essence, they are therefore closely related to the sphere of rights and obligations of a specific person or institution. Crimes against documents pose a threat to the proper functioning of the state and thus the development of every enterprise. They affect, directly or indirectly, the misallocation of financial resources at the disposal of an enterprise. Forging documents may be aimed at obtaining unauthorized access to specific sources of financing, influencing key management decisions made in the company, or, finally, concealing inconvenient facts. On the other hand, the social harm suffered as a result of forging documents of evidence significance in tax matters may be enormous. For this reason, it is necessary to deepen the knowledge
\end{abstract}


of the dynamics characterizing document forgery in the sphere of economic activity in order for the state to activate mechanisms able to prevent this type of crime. The article describes the issues of selected tax frauds in Italy with the use of accounting documents.

Keywords: document forgery, tax fraud, tax crimes, forensic science, questioned document examination

\section{Introduction}

Contemporary document examination involves the need to use the latest technologies and analytical techniques providing the most complete possible body of knowledge on contemporary forensic document examination issues and methods. The examination of classical documents most often involves determining the author of a particular entry or signature on a document by comparing handwriting or computer-generated "handwriting." It may also include detecting changes in a document due to the use of a photocopier or printer as well as various types of computer manipulation, the reconstruction or decryption of erased and obliterated writing, the visualisation of latent entries, the identification of printing processes, and the differentiation of widely understood covering agents (pen pastes, pen gels, pen and printer inks, or printer powders). The examination may also include one of the most difficult research issues faced by forensic science, i.e. examining the age of documents. In the modern world, computer-generated documents are increasingly replacing entirely handwritten ones. The digital revolution we are currently experiencing has undoubtedly accelerated the process of replacing traditional documents with alternatives. Therefore, electronically recorded signatures are becoming more and more common, which makes the knowledge of technological advances and the creation of new validated techniques and methods for examining documents increasingly desirable. ${ }^{1}$

${ }^{1}$ Forensic document examination in the 21st century, eds. M. Angel, J.S. Kelly, Boca Raton, FL 2020, pp. 157-172. D. Ellen, S. Day, Ch. Davies, Scientific examination of documents. Methods and techniques, Boca Raton, FL 2018; D. Ellen, The scientific examination of documents. Methods and techniques, Boca Raton, FL 2003, pp. 1-7; R. Cieśla, Technical examination of documents within the scope of Polish evidence law, Wrocław 2006, pp. 435-441. 
The purpose of documents is to record legal actions and events of legal significance. By their very nature, they are closely linked to the sphere of a specific person or institution's rights and obligations. They ensure efficiency and security of widely understood legal transactions. Sometimes they are the only proof of possession of certain rights or a title to receive a given good. Documents also perform important functions in finances. Even these briefly presented uses clearly indicate the necessity to take all possible and necessary steps to ensure the credibility of documents. Crimes against documents constitute a threat to the proper functioning of the state and, consequently, to the development of every enterprise. They directly or indirectly affect improper allocation of financial resources available to a business entity. Falsification of documents may aim at gaining unauthorized access to specific sources of financing, influencing key management decisions made in a company, or covering up inconvenient facts. A beneficiary of falsification may be an ordinary employee, a specific department or division of an entity, or, in extreme cases, a business entity. Forgery of documents, which is a negative phenomenon in itself, is not only a serious offence punishable under criminal laws of the states, ${ }^{2}$ but also it is above all a preliminary, preparatory behaviour to much more serious offences that directly or indirectly damage the interest and security of the state. ${ }^{3}$

2 In Italy, the falsification of documents is penalised by the Penal Code (Codice Penale Italiano) approved by Royal Decree No. 1398 of 19 October 1930, articles 476493, Gazzetta Ufficiale (OJ) No. 251 of 26 October 1930.

3 Money laundering is criminalized in the Italian Penal Code in Book II - On crimes in particular, Title XIII - Crimes against property, Chapter II - Crimes against property through fraud. Article 648-bis of the I.P.C., enacted by Legislative Decree 59/1978, stipulates: "whoever, except in cases of participation in a crime, substitutes or transfers money, goods, or other gains resulting from a non-culpable crime, or carries out activities related to a crime in order to impede the identification of their criminal origin, shall be punished by imprisonment for a term of four to twelve years and a fine of between $€ 5,000$ and $€ 25,000$." In turn, article 640 of the I.P.C., Book Two - On crimes in particular, Title XIII - Crimes against property, Chapter II - Crimes against property by fraud. Whoever, by deception or fraud, misleads someone, causing harm to himself or others, shall be punished by imprisonment from six months to three years and a fine from 51 euros to 1032 euros. Imprisonment from one to five years and a fine from 309 euros to 1549 euros shall be applied: 1) if the fact has been committed to the detriment of the State or another public authority or of the European Union, or under the pretext of releasing someone 
Forgery of documents, which can take the form of intellectual falsification or material forgery, is an offence defined by the Italian Penal Code (I.P.C.). Intellectual forgery refers to the case of certifying an untruth in a document. ${ }^{4}$

Indeed, the I.P.C. treats as an intellectual forgery only when the content of the document relates to the sphere of public activity. According to article 479 of the I.P.C., intellectual forgery is the concealment of the truth of a real situation. The characteristic of this offence is the risk of the offence itself and not the damage that could result from it. In particular, articles $479-493$ of the I.P.C. define the penalties for intellectual impersonation of a public officer or appointed public official, committed in a public act. Article 480 of the I.P.C. deals specifically with certificates and administrative authorisations, while article 483 tackles sanctions against private individuals committing intellectual forgery in a public act. Italian case law defines the document as an object of legal protection - protection of the authenticity and truthfulness of the public document not only as an evidentiary instrument, but also as a means by which public activity is carried out. In intellectual forgery, it is an element of the offence for an official to certify an untruth in a document that has legal significance. An example of such a document is a residence permit. The psychological element of this offence is the awareness and the will to falsely certify something in an official document (art. 2699 I.P.C.). Material forgery, on the other hand, occurs when an authentic document is forged or counterfeited in its entirety or in a specific part. Article 5, $\S 8$-bis of the Legislative Decree on

from military service (7) (8);2) if the fact has been committed causing the victim to fear an imaginary danger or to mistakenly believe that it is necessary to comply with an order of the Office [649] (9); 2-bis) if the fact has been committed in the presence of a circumstance referred to in article 61(5)(10). The offence shall be punishable at the request of the victim, unless there is one of the circumstances provided for in the preceding paragraph or an aggravating circumstance referred to in article 61(1)(7) (11).

${ }^{4}$ Italian Penal Code (Codice Penale Italiano) approved by Royal Decree No. 1398 of 19 October 1930, articles 476-493, Gazzetta Ufficiale (OJ) No. 251 of 26 October 1930. Article 476 of the Italian Penal Code reads as follows: "A public official who, in the exercise of his functions, creates in whole or in part a false act or alters a true act, shall be punished by imprisonment of one to six years. If the falsification concerns an act or a part of an act, which until the filing of a complaint of falsification is considered real, the punishment of imprisonment shall be from three to ten years." 
Immigration defines two types of offences relating to material forgery for the purpose of obtaining entry and residency permits for foreigners: forgery or falsification of a residency permit (art. 5, § 8-bis of Legislative Decree 286/98). This provision, introduced by Legislative Act 189/02, concerns anyone who forges or falsifies an entry or return visa, a residency permit, a residence contract, or a residence card (currently called the EU residency permit for long-term residents), or falsifies other certificates with the aim of obtaining the above-mentioned documents allowing entry into residency in Italy. Whoever commits these crimes is punished with imprisonment from one to six years. In article 476 I.P.C., the legislator has also provided for penalties that are one-third more severe for public officials who commit this type of offence. ${ }^{5}$

The list of cases related to criminal behaviour by persons involved in document forgery is quite long. Most frequently it includes organised crime, economic and financial crimes, crimes against a person, property, and public trust. One of the most recent phenomena showing close connection with forgery of documents is illegal deduction of amounts of taxes due. ${ }^{6}$

The social harm done as a result of falsifying documents of evidential value in tax matters is considerable. The first victim is certainly the state, since it does not receive the assets due in tax; others include honest members of companies who, unaware of the fraudulent mechanism, may become involved in the criminal procedure (criminals often use data of third parties, ignorant of their role in the crime). Furthermore, tax evading companies are able to sell their products at more favourable prices and are thus more competitive, damaging free and fair market competition. All the above-mentioned factors also have political implications. Tax evasion by companies that are growing rapidly due to their crime can increase the tax burden on honest, already operating companies that meet their tax obligations. For this reason, it is necessary to

5 R. Cieśla, J. Grębowiec-Baffoni, "Problematyka fałszerstw zezwoleń na pobyt we Włoszech", Człowiek i Dokumenty 53, 2019, pp. 21-32.

6 J. Sawicka, A. Strączek, E. Marcinkowska, "Przestępstwa przeciwko wiarygodności dokumentów jako obszar zainteresowana audytu zewnętrznego", Studia i prace Kolegium Zarządzania i Finansów Szkoła Główna Handlowa 152, 2016, p. 96; J. Wojtasik, "Fałszerstwo dokumentu", Prokuratura Okręgowa w Zielonej Górze, http://www.zielona-gora.po.gov.pl/index.php?id=36\&ida=2858 (accessed: 10.12.2020). 
deepen the knowledge of the dynamics characterising document forgery in the sphere of economic activity in order for the state to activate mechanisms preventing this type of crime.

In practice, tax fraud is detected too late, often during legal proceedings due to actions taken by law enforcement agencies. The phenomenon of economic and financial crime is important in that a falsified accounting document only produces extra-legal effects after a certain period of time, for example after a complex process of posting or declaring for tax purposes.

\section{The function of accounting documents in company accounts}

Tax fraud in Italy is on the increase despite the constant commitment of the tax authorities to combat it. Moreover, this phenomenon has taken on transnational characteristics, making the task of those responsible for controlling, preventing, and curbing it more difficult. ${ }^{7}$

Experience shows that tax fraud stems from the misuse of certain accounting and/or corporate or commercial documents. The resulting offences, in addition to causing damage to public treasuries caused by the failure to receive the amounts due in accordance with the applicable legislation, also have a serious impact on the relationship of trust that usually develops over time between the company and all those who place legitimate hopes and/or expectations in it (stakeholders). The main accounting document from which this trust develops is the company's balance sheet.

Nowadays, in an increasingly dynamic and globalised economy, the balance sheet is no longer limited to an internal information function, but has grown into a document intended for publication. Initially it was used to make the companies' shareholders aware of their managements' actions and at the same time provide them with periodic economic results. Over the years, it has taken on a much broader public and

7 Data on the amount of tax fraud in Italy: Documento di Economia e Finanza 2020. Nota di Aggiornamento. Relazione sull'economia non osservata sull'evasione fiscale e contributiva 2020 (art. 10-bis.1 c. 3 Legge 31 dicembre 2009, n. 196), https://www. finanze.gov.it/export/sites/finanze/.galleries/Documenti/Varie/Relazione_evasione_fis cale_e_contributiva_-Allegato-_NADEF_2020.pdf (accessed: 25.02.2021). 
outward-looking information function. It is central to the expectations of a wide range of stakeholders (suppliers, customers, banks, investors, employees, etc.) who, necessarily, are at an information disadvantage. This is primarily because those reading the financial statements are outside the company and therefore did not participate in its decisions, so they do not know their origin or results. Moreover, financial statements are a summary document containing selective information, which is also prepared in accordance with the company's communication policy.

For these reasons, the person reading the balance sheet must rely on their own considerable interpretative efforts. The degree of difficulty increases when the mutual information exchange relationship between the company and external parties does not take place in a transparent and correct manner.

Before dealing with ways of manipulating the information process on which the business-external relationship is based, it is necessary to describe the cycle leading to the creation of the balance sheet. Indeed, it is in the nature of the administrative accounting document of the balance sheet that all its fragility lies, given that it is in the accounting process that the risk of damaging action can occur.

The first representation of the company's operations (speaking in technical language: of "corporate events" or "management facts") is found in the documents supporting the operations (invoices, receipts, correspondence, telegrams, letters of intent, contracts, etc.). The management facts, represented by the related accounting documents, must then be recorded in the so-called accounting records (a structured set of written documentation concerning the company, suitable for keeping a faithful record of the company's facts). With advanced accounting methods applied to the set of records, we arrive at the formulation of the financial statement document, which represents the epilogue of the accounting process initiated by the management facts.

The accounting process, understood as the process of defining and expressing in mathematical language business facts and operations that can be conveyed in monetary terms, is designed to enable the preparation of financial statements and to determine the profitability of the company (profit or loss) as well as the consistency of its assets (Figure 1). 


$\begin{array}{cccc}\begin{array}{c}\text { Management } \\ \text { facts }\end{array} & \begin{array}{c}\text { Accounting } \\ \text { documents }\end{array} & \begin{array}{c}\text { Accounting } \\ \text { records }\end{array} & \begin{array}{c}\text { Balance } \\ \text { sheet }\end{array}\end{array}$

\section{Accounting process}

Figure 1. Source: own elaboration

It is, of course, essential that the transcription of the documents supporting the management facts is correctly carried out in the letters, and a correct summary of the results of the entries is necessary in financial statements. The first risk that stands out is that the facts to which the documents refer never took place ("objective non-existence") and the accounting documents contain false data ("subjective non-existence" when the transaction refers to parties other than the ones concerned, and "relative non-existence" when the falsehood concerns remuneration or VAT whose indicated amount is different from the real one). Take, for example, the main tax document, the invoice. It is a typical document certifying the commercial relationship between economic operators, intended to ensure the regularity of the relationship as well as to provide the financial administration with information considered important for tax purposes. This document is issued by the seller of goods or the service provider, giving them the right to collect the amount indicated. An invoice presupposes the existence of a legal transaction in which essential elements are indicated. In terms of taxation, it can be considered one of the main documents, since it is proof of the commercial transaction and its taxability. Precisely because of the special nature of the invoice, the law stipulates that this document contains certain essential elements, regardless of whether paper or electronic format is used and how the information is placed in its text. In any case, it must contain the details of the parties to the transaction, a description of the goods or services supplied, the price, the taxable amount for VAT purposes, and the VAT rate applied.

On the basis of constitutive elements of the invoice, it is possible to confirm the veracity of the whole document: if even one of the parts summarised in it does not correspond to the transaction carried out, it is enough to consider the whole transaction as fictitious. This situation would be of significant fiscal importance given that the numerical values relevant for determining the taxable amounts would also be considered false. 
With regard to tax evasion, the offence of issuing invoices for nonexistent transactions occupies an important place. The criminal conduct manifests itself from the very beginning of the process of realising a false document, which in most cases will lead to the application of that document and thus to concretising the offence of fraudulent tax declaration - fully realising the objective of allowing third parties to evade taxes. The issuance and application of false documents are offences related to the same objective, which means that the first is a means to the realisation of the second. Usually, the person issuing a false invoice in the name of another entity (the potential user) comes to a prior agreement with them. The phenomenon of false invoicing can lead to a series of "tricks" aimed at circumventing indirect taxation (VAT evasion), making it possible to create a commercial circuit in which activity is carried out only at a formal level (usually the goods do not change location), thanks to the action of companies commonly referred to as paper mills (ones that only issue "paper," but never actually operate) and filter companies (designed to lengthen the chain of companies involved in the fraud in order to complicate identifying the criminal mechanism). These entities do not declare their earned income and sometimes have neither employees nor the means to transport the object of sale.

It is clear that anyone who operates by taking advantage of a fraud mechanism created by the fictitious intervention of other companies, whose sole purpose is producing false accounting documents, usually applies the complex accounting and documentation necessary to commit the fraud and lose the traces of the financial operation. In addition to illegally obtaining a tax reduction, it should be noted that in many cases tax violations alter the results of operations by manipulating the values of costs and revenues. For example, in the case of invoicing non-existent transactions, a double result will occur. On the one hand, the fictitious beneficiary will be able to prove, through a document, that he has incurred costs or expenses; on the other hand, the transferor will be able to justify the operation actually carried out "in the black," omitting the due payment to the state. It follows that the perpetrators may be very numerous and may develop their clandestine activities on more levels thanks to the introduction of more intermediaries. At the same time, in the case of a discrepancy between the actual transaction and its documentation 
(i.e. documentation concerning only one part of the operation), although the transaction was actually carried out, the invoice will show an amount (for example) higher than the actual one. This is so-called over-invoicing, making the operation appear non-existent for that part of the surplus. This is one of the most insidious cases of forgery from an evidentiary standpoint, especially when the payment - seemingly constant and complete - indicated on the invoice is followed by a partial reimbursement, with a combination of appropriate methods that constitute an obstacle to the reconstruction of the related financial flows. The transfer of falsified data to the financial statements by indicating fictitious costs in the accounting data may affect the falsification of the financial balance.

Continuing the analysis, it is worth considering the case where a company has issued invoices for services which in reality were never rendered: on the one hand, it can be said with certainty that such a procedure allowed a third party (usually a user) to save tax unduly. On the other hand, the same procedure, to the extent that by indicating "fictitious revenues" the tax base was increased, could at the same time influence higher results of economic activity in comparison with real data. This possibility jeopardises the good protected by law, the transparency and truthfulness of corporate information, and can also be used for specific purposes such as, for example, the desire to present a better financial performance to lenders in order to obtain more financing. Indeed, it is important to emphasise that the balance sheet is not created from an automatic epilogue of records but from the choices of broader corporate strategies, which, however, become disadvantageous as they move through the opaque terrain of manipulation.

\section{Case of evasion of value added tax (VAT) by means of false invoices}

The case in question relates to a recent investigation by Italian tax authorities. ${ }^{8}$ As is known, a company cannot change its accounting information on its own without input from other natural or legal persons.

8 The crime is defined in Italian Legislative Decree No 70 of 2010 and the investigation was conducted by the Guardia di Finanza. 
The falsification of company documents necessarily implies the use of data relating to third parties, more or less aware of the precise objective of the crime. In fact, the investigation allowed the reconstruction of an illegal scheme in which as many as 50 companies participated, to various degrees. The lengthy investigative follow-up made it possible to determine the exact role of each company in the overall fraud scheme. The perpetrators were identified immediately and turned out to be individuals who did not hold any formal positions in the companies involved. Based on the elements gathered during the investigations, it was established that a criminal organisation had committed VAT fraud in the food trade sector. The organisation acted in the following way in order to illegally take possession of the VAT which it should have paid into the state coffers:

1. the first step included identifying companies with large VAT debts generated by perfectly legal activities (so-called launching companies). These were generally medium-sized or large companies with a significant number of transactions that provided services or goods to end customers such as electronics chains, supermarkets, hypermarkets, and discount shops;

2. once the launching companies had been identified, members of the criminal organisation would propose - to the heads of the purchasing departments or directly to the directors of these companies - that instead of paying the proportion of VAT due to the state they should transfer the tax obligation to another company designated by the same parties and obviously belonging to the criminal organisation (the so-called filter company).

To make the proposal more attractive, a remuneration of between $6 \%$ and $8 \%$ was offered to the triggering company, awarded in successive phases of the fraudulent scheme. If the launching company accepted the criminal proposal, the first accounting document was falsified: an invoice confirming the sale of goods by the filter company to the launching company. According to the law in force, the invoice issued by the filter allowed the launching company to calculate a (fictitious) VAT value, equal to the VAT indicated on the invoice. In this way, the obligation to pay was transferred from the launching company to the filtering company. 
After this initial phase, the criminal plan developed in stages.

Stage 1. The criminal organisation identified to the launching company a foreign company (which we will call a conduit company) to which the previously purchased goods had to be resold. This was a community company managed, in reality, by the same criminal organisation that "bounced" the goods before sending them back to Italy. The resale of the goods from the launching company to the conduit company took place by means of an invoice, not subject to VAT. Here a surcharge was applied, on average around 6 to $8 \%$ on the purchase price - for example, the pass-through company sold goods previously purchased for 100 with an $8 \%$ profit surcharge (108).

Stage 2. The conduit company invoiced the same goods to another pass-through company based in another European Union country, applying a surcharge of $3 \%(108+3 \%$ profit $=11.24)$. The sole function of this transfer, foreign to other countries and also not subject to VAT, was hindering the reconstruction of the fraudulent supply chain further, making the control authorities' task more difficult.

Stage 3 . The second pass-through company invoiced the same goods to the paper mill company again, applying a 3\% surcharge; this transaction too was not subject to VAT $(111.24+3 \%$ profit $=114.57)$.

Stage 4. The paper mill, having received an invoice without VAT from the pass-through company, in turn invoiced the filter company (the so-called first level filter) with VAT because it was a domestic transfer. The invoice issued by the paper mill indicated a taxable amount (in our example 95.09), which is about 17\% lower than the amount indicated on the intra-community purchase invoice. The paper mill was operating systematically below cost.

Stage 5. The first level filter re-invoiced the same goods to another filter (second level filter), generally applying a minimum profit of $1.5-2 \%$ $(95.09+2 \%$ profit $=97)$. Such "passing" essentially served to make fraud reconstruction more difficult for investigating authorities.

Stage 6 . The second level filter could in turn issue a sales invoice to the same launching company if it still had a VAT debt, or it could issue an invoice to another vulnerable company with a significant VAT debt, i.e. another launching company. 
The second-level filter, i.e. the second entity dealing with the purchase and sale of non-existent goods, which charged a margin of 2.5 to 3 percent from the profit for this "service," 97 is an example of the profit sum obtained from the first-level filter, to which, after adding a 3\% margin, the sum was 99.91, approximately 100 .

It should be noted that the launching company ended its involvement by repurchasing the same goods at the same price (100). In essence, the cyclical chain of transactions is merely a tool enabling the criminal organization to take possession of VAT, bypassing the obligation to remit it to the state, which should be done by the launching company and which, on the basis of false invoices, therefore fell to the paper mill. It was therefore irrelevant for the purposes of the fraud whether the goods - the subject of the false invoices - actually existed, and even if they had, it would not have made any difference whether they were transported or not. In this type of fraud no goods are physically moved: all stages are purely "paper." In fact, often the same goods remain the object of purchase and resale for years (precisely because it is sufficient to indicate this on the false invoices). In the presented system there was no real purchase or sale transaction, except for the (illegal) purchase of the VAT debt by the criminal organisation from the launching company, in return for which the latter received a substantial profit of $8 \%$.

\section{Conclusions}

The analysed case illustrates how the objective of tax evasion can be achieved by using false accounting documents which prove the movement of goods that never took place. As has been presented, such complex fraud requires the participation of various actors: each link in this fraudulent chain plays a specific role. Essential here is the role of paper mills, whose sole reason for existence is "producing paper" (i.e. printing false invoices). Filter and pass-through companies, on the other hand, do not carry out real economic activity and do not have an effective corporate structure: they are used to prolong the illicit chain and make it difficult to identify the criminal organisation's targets. As has been shown, the role of the only genuinely existing and operating company (pass-through) - corrupted and entangled in the schemes - is to evade 
tax obligations through the promise of additional profit. Placed at the top of the various corporate structures are people lending their name (socalled poles), where in reality these companies are managed by third parties who want to remain hidden from the tax authorities.

In Italy, the social harmfulness of falsifying documents in the tax sector is further increased by the fact that the control action is only possible after the social harm has been realised. ${ }^{9}$

In addition to this, a tax document that is not limited to reflecting reality but significantly alters it by incorporating it - as we have seen - into a broader system of accounting records, undermines the credibility of the entire balance sheet presented by the company, creating false expectations for a high number of entities. Some companies engaged in counterfeiting for tax evasion purposes usually do not present any budget, preferring to leave the economic scene after a year or two of illegal activity (this is a typical case for paper mills). After their closure, other new "businesses" belonging to the same entities appear, which makes it more difficult for law enforcement and judicial authorities to combat criminal structures.

\section{References}

Cieśla R., Technical examination of documents within the scope of Polish evidence law, Wrocław 2006.

Cieśla R., Grębowiec-Baffoni J., "Problematyka fałszerstw zezwoleń na pobyt we Włoszech" [Problems of fraudulent residence permits in Italy], Człowiek i Dokumenty [Man and Documents] 53, 2019.

Documento di Economia e Finanza 2020. Nota di Aggiornamento. Relazione sull'economia non osservata sull'evasione fiscale e contributiva 2020 (art. 10-bis. 1 c. 3 Legge 31 dicembre 2009), n. 196, https://www.finanze.gov.it/export/sites/finanze/. galleries/Documenti/Varie/Relazione_evasione_fiscale_e_contributiva_-Alleg ato-_NADEF_2020.pdf (accessed: 25.02.2021).

Ellen D., The scientific examination of documents: Methods and techniques, Boca Raton, FL 2003.

9 "Fisco, lavoratori autonomi e imprese evadono il 70\% delle tasse: allo Stato mancano oltre 100 miliardi l'anno", https://it.businessinsider.com/evasione-fiscale-auto nomi-imprese-tasse/\#: :text=Secondo $\% 20 \mathrm{il} \% 20 \% \mathrm{E} 2 \% 80 \% 9$ Crapporto $\% 20$ sui $\% 20$ ri sultati,ammonta\%20al\%2068\%2C8\%25 (accessed: 2.03.2021). 
Ellen D., Day S., Davies Ch., Scientific examination of documents. Methods and techniques, Boca Raton, FL 2018.

"Fisco, lavoratori autonomi e imprese evadono il 70\% delle tasse: allo Stato mancano oltre 100 miliardi l'anno" [Tax authorities: self-employed people and companies avoid paying $70 \%$ of taxes: the state loses more than 100 billion a year], https://it.busi nessinsider.com/evasione-fiscale-autonomi-imprese-tasse/\#: :text=Secondo $\% 20$ il $\% 20 \%$ E2\%80\%9Crapporto $\% 20$ sui $\% 20$ risultati,ammonta $\% 20 \mathrm{al} \% 2068 \% 2 \mathrm{C} 8 \% 25$ (accessed: 2.03.2021).

Forensic document examination in the 21st century, eds. M. Angel, J.S. Kelly, Boca Raton, FL 2020.

Italian Penal Code (Codice Penale Italiano) approved by Royal Decree No. 1398 of 19 October 1930, Articles 476-493, Gazzetta Ufficiale (OJ) No. 251 of 26 October 1930.

Sawicka J., Strączek A., Marcinkowska E., "Przestępstwa przeciwko wiarygodności dokumentów jako obszar zainteresowana audytu zewnętrznego" (Crimes against the credibility of documents as an area of interest of internal auditing), Studia $i$ Prace Kolegium Zarządzania i Finansów (Studies and Works of the Collegium of Management and Finance) 2016, no. 152.

Wojtasik J., "Fałszerstwo dokumentu" [Document forgery], Prokuratura Okręgowa w Zielonej Górze, http://www.zielona-gora.po.gov.pl/index.php?id=36\&ida=2858 (accessed: 10.12.2020). 